\title{
Significance of vegetable and fruit processing industry with a special regard on berries and nuts
}

\author{
Kurmai, V. \& Apáti, F. \\ University of Debrecen, Faculty of Economics and Business, Institute of Management Sciences; \\ H-4032 Debrecen, Böszörményi Street 138.
}

\begin{abstract}
Summary: The main goal of our paper is to evaluate the economic performance of processing industry and its significance within food industry, furthermore to define economic weight of processed goods made of nuts and berries. Fruit and vegetable processing industry plays a key role in Hungarian food industry: it provides $10 \%$ of its production value and revenue, its export is outstanding and its export-import balance was positive in the last 15 years. Purchase of berries has been continuously reduced in the processing industry, mostly raspberry and blackberry decreased. Nut products is and important group; their revenue was $12 \%$ of the industry's revenue in 2012. Processed goods made of nuts and berries are high added value products, while the purchased quantity is small, the value of finished products is high, especially in case of nuts.
\end{abstract}

Keywords: fruit, vegetable, fruit processing, berries, nuts

\section{Introduction}

Hungary is engaged in widely acknowledged agricultural production for thousands of years thanks to its natural conditions, from which major part is processed by food industry (Hajdú-Lakner, 1999). In the last 30 years food industry had to face a change of regime, EU-accession and a global economic crisis, which put the industry in difficult situation (Gyarakay, 2013). Despite food industry managed to maintain its importance, as it has the third greatest output regarding processing industries and it employs the most people. The food industry's share in national gross output and added value but it is decreasing, in spite of the fact its value is increasing. The share of output in 2012 was equal to the share in 2005, which assumes an increase.

Main objective of the paper is to evaluate the economic performance of fruit and vegetable processing industry and its significance within food industry, including the definition of the economic weight (production, commerce) of processed products made of nuts and berries.

\section{Materials and methods}

Databases needed were provided by KSH (Központi Statisztikai Hivavatal - Hungarian Central Statistical Office) and Fruitveb Association of Vegetable Fruit Producers (Fruitveb MagyarZöldség-Gyümölcs Szakmaközi Szervezet). In case of KSH data mainly publicly available information database were used but required data were also included in a smaller amount, where nomenclature of TEÁOR'08 and MNK was processed. Sectoral-statistical data of Fruitveb is revealed in the year assessment bulletins published annually, out of which data regarding processed industry were collected and ordered yearly. The period of analysis is between 2000 and 2013, data were summarized and processed in Microsoft Excel. In order to present the condition of fruit and vegetable processing industry descriptive statistical methods were applied. To have a clear view of the analysed product group it is important to distinguish the operation of three sub sectors of fruit and vegetable processing and preserving sector:

- Companies of potato processing and preserving sub sector produce the processed and preserved potato products and carry out the industrial peeling.

- Fruit and vegetable juice sub sector deals with producing juices and concentrates gained from fresh fruits and vegetables.

- The widest product range is offered by the other fruit and vegetable processing and preserving sub sector. Products like frozen and canned fruits and vegetables, dried products, products preserved with vinegar or oil, jellies, marmalades, jams and products made of walnut belong here.

In this study the significance of nuts and berries are evaluated in the processing industry, these products are mainly processed by other fruit and vegetable processing and preserving industry and in a smaller amount by juice industry.

\section{Results}

The significance of fruit and vegetable processing industry within food industry

Hungarian food industry can be divided to 9 sectors and 25 sub sectors based on the KSH defined nomenclature. Fruit 
and vegetable processing sector contributed to production value and revenue of food industry with $9-10 \%$ in the last 15 years, so the significance of the analysed sector within food industry remained constant. It is in the $6^{\text {th }}$ place out of the 9 sectors based on both performance indicators.

Fruit and vegetable processing industry is strongly export-oriented, it has the $3^{\text {rd }}$ greatest revenue among sectors regarding export revenues, it represents $15-17 \%$ of the food industry's export revenue between 2000 and 2013. Domestic revenue of the sector is $6-7 \%$ of the total domestic revenue of food industry, which means the last place regarding all sectors. The ratio of export and domestic trade is just the opposite like in 2004, when $65 \%$ of the revenue came from domestic trade but this value was characteristic to the revenue of export trade in 2013.

Import products of fruit and vegetable processing industry increased by $50 \%$ in the analysed period and their value increased with more than $100 \%$. Export products increased only by $16 \%$, while their value doubled. Export and import product structure has been rearranged in food industry. As a result, export share of products made of vegetables, fruits, walnuts and other parts of plants within food industry halved, while import share diminished minimally.

Employees in domestic fruit and vegetable processing industry decreased by $41 \%$ to year 2013 compared to the data of 2000. This ratio exceeds a $33 \%$ employment decline of the total food industry employment. This tendency stagnates in the last couple of years. The ratio of the employment within food industry mitigated form $11,4 \%$ to $8,7 \%$. The number of companies in fruit and vegetable processing industry increases, while the number of food industry companies decreases, therefore the ratio of analysed sector is clearly growing.

\section{Significance of nuts and berries in vegetable and fruit processing industry}

Raw vegetable and fruit purchase showed a declining tendency between 2003 and 2012, its value decrease from 1.6 million tons to 1.4 million tons. The quantity of the purchased raw material is increasing or decreasing proportionally to the quantity, although inflation and price rise is also influential: processing industry purchased 1.6 million tons raw material for 48 billion HUF in 2003, in 20121.3 million tons worth 71 billion HUF. (Figure 1) Mainly four products provided the basis of the sector's production: $70-80 \%$ of the purchased raw material is cherry, peas, sweet corn and apple. There is hard evidence in Figure 1 that the processed finished product worth 3-3.5 times more than the purchased raw material, while its quantity is $30 \%$ less, which is the result of the processing loss. The production of vegetable and fruit processing industry has not changed significantly in the last 12 years. The least product ( 0.8 million tons) was produced in 2005 and the most (1.1 million tons) in 2002. The sector was capable of selling $91 \%$ of the produced amount, but it also occurred that this ratio was only $81 \%$ and once it succeeded in selling $15 \%$ more than current year's product.

Table 1 shows the purchased quantity and value of berries. While $15 \%$ of the purchased fruits by the processing

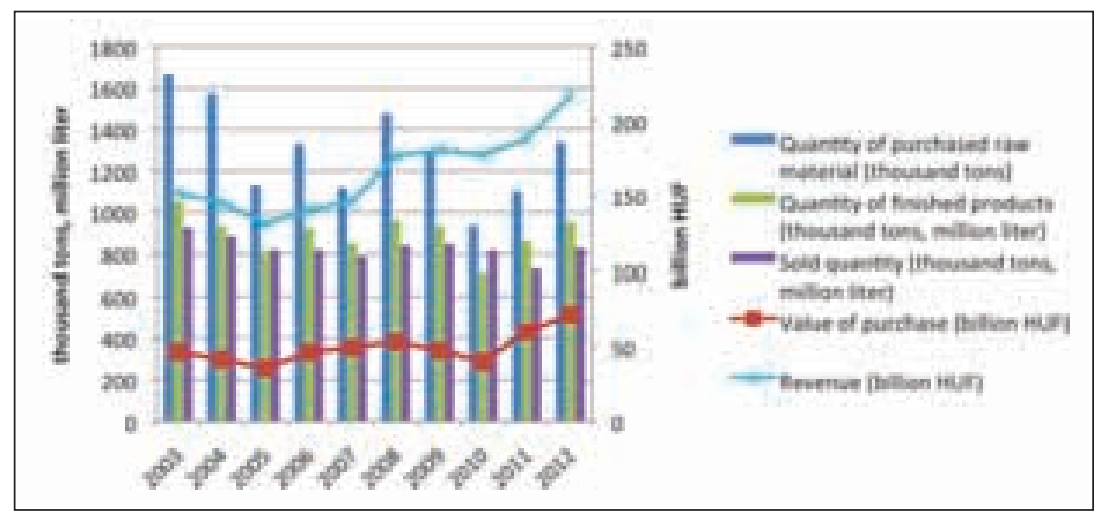

Source: Fruitveb (2013) és KSH (2013)

Figure 1: Purchase and selling data of vegetable and fruit processing industry (2003-2012) industry were berries in 2003, nowadays this ratio is only $4 \%$. Purchase of raspberry declined the most dramatically, however processing of blackberry is also about to disappear. The purchase of nuts represents minimal quantity and its value is also insignificant among processed raw materials. Considering the value and quantity, purchase is rather narrowed to the abovementioned 4 types (cherry, peas, sweet corn, and apple): today these represents $82 \%$ of the quantity and $72 \%$ of the value of the total purchased vegetables and fruits. This supports the view of Erdészné (2008). Out of the four leading species apple and sweet corn are outstanding, which represented half of the value and $73 \%$ of the quantity regarding purchased raw materials.

Vegetable and fruit industry has 3 subsectors, out of which the greatest value generating subsector carries out the processing of nuts and berries. Based on TEÁOR nomenclature processing of nuts and berries belongs to the product group of "processed and preserved fruit and nuts".

"Processed and preserved fruit and nuts" producers manufactured 157 thousand tons of finished products in 2012, which meant 58 billion HUF revenue. (Figure 2) Products are more likely to be sold on export markets, $60 \%$ of the products got abroad in 2012. The value of "processed and preserved fruit and nuts" products have a significant share, i.e. relatively small quantity represents a high value. Semi-finished canned fruits and nuts had the highest ratio in the product group in 2000, 81 thousand ton finished products were produced, resulting in 1.6 billion HUF revenue. In 2012 4 thousand tons generated only half billion HUF revenue.

Regarding the structure of product group 'processed and preserved fruit and nuts' the following main conclusions can be stated: (Figure 2):

- The production of processed and preserved walnuts and peanuts has doubled; their revenue has increased fivefold since 2000. 50 thousand tons of products were made, which resulted 26 billion HUF revenue. Major 
Table 1: Berries and nuts purchase of vegetable and fruit processing industry between 2003 and 2012

\begin{tabular}{|l|r|r|r|r|r|r|r|r|r|r|r|r|}
\hline \multicolumn{1}{|c|}{ Products } & $\mathbf{2 0 0 3}$ & $\mathbf{2 0 0 4}$ & $\mathbf{2 0 0 5}$ & $\mathbf{2 0 0 6}$ & $\mathbf{2 0 0 7}$ & $\mathbf{2 0 0 8}$ & $\mathbf{2 0 0 9}$ & $\mathbf{2 0 1 0}$ & $\mathbf{2 0 1 1}$ & $\mathbf{2 0 1 2}$ \\
\hline \multicolumn{10}{|c|}{ Volume (thousand tons) } \\
\hline Red currant & 1,3 & 1,6 & 1,8 & 1,5 & 1,4 & 2,1 & 2,2 & 2,0 & 2,0 & 2,1 \\
\hline Black currant & 0,5 & 0,7 & 0,8 & 0,8 & 1,0 & 1,7 & 1,7 & 1,5 & 1,0 & 2,0 \\
\hline Strawberry & 1,1 & 1,1 & 1,3 & 0,8 & 0,5 & 1,1 & 1,2 & 0,8 & 0,8 & 1,2 \\
\hline Blackberry & 2,9 & 3,9 & 3,9 & 3,9 & 3,5 & 4,3 & 4,0 & 1,6 & 0,6 & 0,7 \\
\hline Raspberry & 6,6 & 6,6 & 6,7 & 6,6 & 4,8 & 6,3 & 5,8 & 3,1 & 0,3 & 0,4 \\
\hline Gooseberry & 0,5 & 0,6 & 0,7 & 0,5 & 0,2 & 0,3 & 0,3 & 0,2 & 0,1 & 0,1 \\
\hline & \multicolumn{8}{|c|}{ Value (million huf) } \\
\hline Strawberry & 205 & 152 & 176 & 136 & 106 & 241 & 307 & 239 & 258 & 467 \\
\hline Black currant & 51 & 21 & 30 & 40 & 71 & 269 & 201 & 199 & 203 & 243 \\
\hline Red currant & 205 & 152 & 176 & 136 & 106 & 241 & 307 & 239 & 258 & 467 \\
\hline Raspberry & 1680 & 1326 & 1236 & 1315 & 1096 & 1430 & 1794 & 1108 & 290 & 190 \\
\hline Blackberry & 397 & 410 & 402 & 421 & 553 & 501 & 432 & 298 & 121 & 165 \\
\hline Gooseberry & 133 & 126 & 141 & 35 & 26 & 33 & 36 & 28 & 15 & 18 \\
\hline
\end{tabular}

Source: Fruitveb (2013)

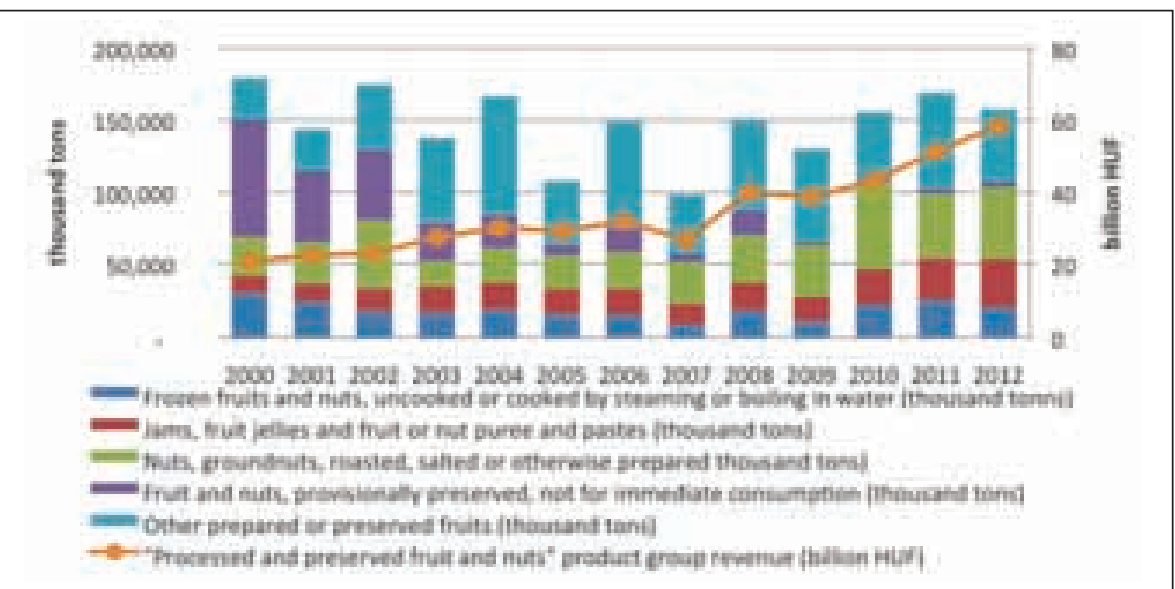

Source: KSH (2013)

Figure 2: Production structure and quantity of 'processed and preserved fruit and nuts' product group (2000-2012)

part of the products was sold in domestic markets. Walnuts and peanuts provide $31 \%$ of the production and $45 \%$ of the revenue in the product group

- In 2012 frozen fruits and nuts represented 13\% of the product group. The quantity of the manufactured product declined from 30 thousand tons to 20 thousand tons with 7 billion HUF revenue. $75 \%$ of the products are sold in export markets.

- "Jams, fruit jellies and fruit or nut puree and pastes" products were sold only in Hungary, for today $3 / 4$ of it go on export sale. Its production tripled since 2000, 34 thousand tons of finished products are produced to 2012. Its revenue is also significant: it is currently 9.6 billion HUF, which was only 2.7 billion HUF in 2000 .

\section{Production structure and external trade of vegetable and fruit processing industry}

If we analyse the product structure of "fruit and vegetable processing and preserving sector", we can come to the conclusion that the product group was unusually narrowed down. Within the sector the greatest portion is represented by "frozen vegetables and fruits and nuts" category: it is $24 \%$ of the produced amount and $18 \%$ of the revenue in 2012. Meanwhile, the produced amount has increased by $15 \%$ and its revenue by $70 \%$ since 2000. In this category the greatest amount produced and the highest revenue provider product group is the "frozen vegetables and fruits".

The sectors' most important products are the "processed and preserved sweetcorn and peas", since a huge amount of these vegetables are processed (ERDÉSZ et.al., 2009). Although their price value is not prominently high, but due to their enormous quantity these are the leading products of the sector: the two products provides $31 \%$ of the subsectors' quantity and $25 \%$ of its revenue. On the contrary "processed and preserved walnuts and peanuts" represents smaller amount, still it contributes with higher revenue to the result of the subsector, which is continuously increasing. Changes occurred in case of "jams, fruit jellies and fruit or nut puree and pastes" products and also in case of apple production. The quantity of the products has significantly increased since 2000, so did their sales revenue. The opposite could be observed in case of pickles, whose produced amount shows a declining tendency.

The ratio of exported and domestic selling reflects a significant change regarding the sector's sales. This ratio was $50 \%-50 \%$ in 2000 , nowadays the sector exports $66 \%$ and sells $34 \%$ in domestic markets (considering both revenue and quantity).

Export-import balance of vegetable and fruit processing industry shows increasing tendency regarding product value (Juhász-Wagner, 2012). Balance of product quantity has barely grown since 2003, which means that the growth of exported quantity is followed by the same proportional growth of the imported good's quantity (Table 2).

Quantity of the exported products increased by $15 \%$ but their values by $70 \%$. However the quantity of imported goods has been growing by $50 \%$ since 2003 and their values have reached 2.3 times the original value. Consequently, the processed vegetable and fruit trade shows growth regarding product amount, but product value increased to a higher extent considering the exchange rate and price growth. 
Table 2: Export-import balance of products made of vegetables, fruits, walnuts and other parts of plants (2003-2012)

\begin{tabular}{|l|l|l|l|l|l|l|l|}
\hline \multicolumn{2}{|c|}{ Name } & $\mathbf{2 0 0 3}$ & $\mathbf{2 0 0 5}$ & $\mathbf{2 0 0 7}$ & $\mathbf{2 0 0 9}$ & $\mathbf{2 0 1 1}$ & $\mathbf{2 0 1 3}$ \\
\hline \multirow{2}{*}{$\begin{array}{l}\text { Net weight } \\
\text { thousand } \\
\text { tons) }\end{array}$} & Import & 110,4 & 149,9 & 162,5 & 146,4 & 168,1 & 165,8 \\
\cline { 2 - 8 } & Export & 435,1 & 428,6 & 431,0 & 421,5 & 423,4 & 503,9 \\
\cline { 2 - 8 } & Balance & 324,7 & 278,7 & 268,5 & 275,1 & 255,2 & 338,1 \\
\hline \multirow{2}{*}{$\begin{array}{l}\text { Free-at- } \\
\text { frontier value } \\
\text { (billion HUF) }\end{array}$} & Import & 22,1 & 28,3 & 38,2 & 38,8 & 47,6 & 52,4 \\
\cline { 2 - 8 } & Export & 81,7 & 86,6 & 98,5 & 107,5 & 121,5 & 154,4 \\
\cline { 2 - 8 } & Balance & 59,6 & 58,3 & 60,3 & 68,6 & 73,8 & 102,0 \\
\hline
\end{tabular}

Source: KSH (2012)

According to the nomenclature of KSH MKN 9 product groups are distinguished regarding finished goods made of vegetables, fruits, walnuts and other parts of plants, i.e. regarding products of vegetable and fruit processing industry. Nuts and berried are processed in the following three product groups:

1. Vegetable, fruit, walnut and plant part preserved by sugar

2. Jam, jelly, flavour and puree made of fruits and walnuts

3. Roasted fruits, nuts and edible parts of plants cooked and preserved in sugar syrup, sterilized, and containing added alcohol

"Vegetable, fruit, walnut and plant part preserved by sugar" product group does not contribute significantly to the result of neither export nor import, this is why it is not detailed here.

The significance of product made of "jam, jelly, flavour and puree made of fruits and walnuts" is continuously growing, especially in the field of import. The quantity of both imported and exported goods are increasing - after the low point of 2008, when it has a negative export-import balance - a rapidly increasing tendency characterised the export products. In 2013 it represents 3\% of the exported and $2 \%$ of the imported goods. In terms of value it obtains a higher portion in both export and import.

The export and import significance of "roasted fruits, nuts and edible parts of plants cooked and preserved in sugar syrup, sterilized, and containing added alcohol" products is outstanding: $22 \%$ of export revenue and $17 \%$ of the import revenue is generated by this product group. In the last 10 years this product group was characterized by declining import and growing export, this made the current high balance of exportimport possible. This product group produce a much higher value, as the same amount is equal to twice as much the value of the same amount of peas'

The most significant export product is "walnuts and other nuts and preserved and cherries in sugar syrup". In the last 10 years nuts and other oilseeds contributed to the export revenue by $3 \%$. It is evident, that the quantity increases both in case of export and import and its proportion has been maintained for ten years. Its balance is growing regarding products and its values.

\section{Conclusions}

Out of the 9 subsectors of food industry fruits and vegetable processing and preserving sectors deal with the processing of horticultural products. Since the millennium the analysed sector provides $10 \%$ of the food industry's production value and sales revenue. Its export is outstanding; it had a positive export-import balance in the last 15 years. The berry purchase by the processing industry is continuously decreasing, particularly raspberry and blackberry are in disadvantageous position. Products made of nuts are important product group of vegetable and fruit processing products, its revenue was $12 \%$ of the industry's revenue in 2012. Processed goods made of nuts and berries are high value added products, while quantity of the purchase raw material is low, value of the finished product is very high, especially in case of nuts.

\section{Acknowledgement}

This research was supported by the European Union and the State of Hungary, co-financed by the European Social Fund in the framework of TÁMOP-4.2.4.A/ 2-11/1-20120001 'National Excellence Program'. The identification of the application is: A2-MZPD-13-0358

\section{References}

Erdész F.-né (2008): A hazai zöldség-gyümölcságazat fejlődési kilátásai. Gazdálkodás. 52 (5): 144-151.

Erdészné F., Jankuné K. Gy., Kozak A. \& Radócziné K. T. (2009): A zöldség- és gyümölcságazat helyzete. Budapest. Agrárgazdasági Kutató Intézet. 39-48 p.

Fórián Z. (2005): A tartósítóipar helyzete és kilátásai Magyarországon. Agrár Európa Kft. Budapest

Fórián Z. (2009): AZ EU-csatlakozás vesztese: a magyarországi élelmiszeripar. Agrár Európa Kft. Budapest

Fruitveb (2013): Magyar zöldség-gyümölcs ágazati stratégia. Budapest

Gyarakay Z. (2013): A magyar élelmiszeripar helyzete és megújulásának lehetőségei. Minőség és megbízhatóság. 46 (4): 148-155.

Hajdú I.-né \& Lakner Z. (1999): Az élelmiszeripar gazdaságtana. Mezőgazdasági Szaktudás Kiadó. Budapest

Juhász A. \& W. Harmut (2012): Magyarország élelmiszer-gazdasági export versenyképességének elemzése. Gazdálkodás. 56. (6): 530-541.

Fruitveb A feldolgozóipar nyersanyagfelvásárlási adatai (2001-2013) KSH A kibocsátás és a bruttó hozzáadott érték (2013)

KSH Az ipar termelési és értékesítési adatai szakágazatok szerint 4 fö feletti vállalkozások esetén (2014)

KSH Éves gazdaságszerkezeti adatok létszám kategóriánként (2013) KSH Foglalkoztatottak száma nemzetgazdasági ágak, ágazatok szerint (2013)

KSH Ipari termékek és szolgáltatások éves termelése (2013)

KSH Müködő, valódi új, valódi megszünt vállalkozások száma nemzetgazdasági ág szerint (2013)

KSH Nemzetgazdaság munkaügyi adati (2014)

KSH Termékszintü adatok MKN szerint (2014) 